Original Article

\title{
Seasonal mite population distribution on Caryocar brasiliense trees in the Cerrado domain
}

\author{
Distribuição sazonal da população de ácaros em árvores de Caryocar brasiliense no \\ domínio do Cerrado
}

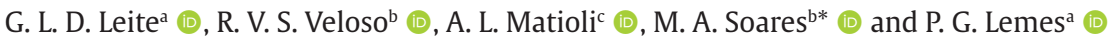 \\ aUniversidade Federal de Minas Gerais - UFMG, Instituto de Ciências Agrárias, Insetário G.W.G. Moraes, Montes Claros, MG, Brasil \\ bUniversidade Federal dos Vales do Jequitinhonha e Mucuri - UFVJM, Departamento de Agronomia, Programa de Pós-graduação em Produção \\ Vegetal, Diamantina, MG, Brasil \\ Instituto Biológico, Laboratório de Acarologia, Campinas, SP, Brasil
}

\begin{abstract}
Caryocar brasiliense Camb. (Malpighiales: Caryocaraceae) trees have a wide distribution in the Cerrado, and it is protected by federal laws. The need to monitor and understand pest damage to crops and forests is a major motivation for the study of population distribution. The mites (Acari) population distributions on C. brasiliense are unknown. We studied seasonal mite population distribution and their ecological indices on C. brasiliense trees in Cerrado areas during three years. Greatest number of Agistemus sp. (Stigmaeidae), Histiostoma sp. (Histiostomidae), Proctolaelaps sp. (Ascidae), and diversity and species richness on leaves of $C$. brasiliense occurred in the autumn; Tetranychus sp.1 (Tetranychidae) on leaves in the autumn and winter; Histiostoma sp., and Proctolaelaps sp. in fruits in the summer. No significant effect of season was observed in the abundance of Eutetranychus sp., Tetranychus sp.2 (Tetranychidae) and Acaridae. The populations of Acaridae, Eutetranychus sp., Proctolaelaps sp. and Tetranychus sp.1 negatively correlated with temperature. Proctolaelaps sp. and Tetranychus sp.1 correlated negatively with rainfall and Eutetranychus sp. and Proctolaelaps sp. positively with sunlight. The period with low rainfall and relative humidity increases the phytophagous mites and their predators, especially Agistemus sp.. The Tetranychus sp. and Histiostoma sp. species may become pests in C. brasiliense in the Cerrado domain.
\end{abstract}

Keywords: Acari, pequi, rainfall, sunlight, temperature.

\begin{abstract}
Resumo
As árvores Caryocar brasiliense Camb. (Malpighiales: Caryocaraceae) têm ampla distribuição no Cerrado e são protegidas por leis federais. A necessidade de monitorar e entender os danos causados pelas pragas às culturas e florestas é uma das motivações para o estudo da distribuição populacional que para ácaros (Acari) em C. brasiliense é desconhecida. A distribuição sazonal de populações de ácaros e seus índices ecológicos em C. brasiliense em áreas de Cerrado foram estudados durante três anos. Maior número de Agistemus sp. (Stigmaeidae), Histiostoma sp. (Histiostomidae), Proctolaelaps sp. (Ascidae) e diversidade e riqueza de espécies nas folhas de C. brasiliense ocorreram no outono; Tetranychus sp.1 (Tetranychidae) no outono e inverno; Histiostoma sp. e Proctolaelaps sp. em frutos ocorreram no verão. Não foram observados efeitos das estações na abundância de Eutetranychus sp., Tetranychus sp.2 (Tetranychidae) e Acaridae. As populações de Acaridae, Eutetranychus sp., Proctolaelaps sp. e Tetranychus sp.1 correlacionaram-se negativamente com a temperatura. Correlações negativas foram observadas entre chuva e Proctolaelaps sp. e Tetranychus sp.1 e positivas entre luz solar e Eutetranychus sp. e Proctolaelaps sp.. Baixa pluviosidade e umidade relativa do ar aumentaram os ácaros fitófagos e seus predadores, principalmente Agistemus sp.. As espécies Tetranychus sp. e Histiostoma sp. podem se tornar pragas em C. brasiliense no domínio do Cerrado.
\end{abstract}

Palavras-chave: Acari, pequi, chuva, luz solar, temperatura.

\section{Introduction}

The Cerrado occupies approximately $23 \%$ of the Brazilian territory and Caryocar brasiliense Camb. (Malpighiales: Caryocaraceae) trees are widely distributed in this region (Pinheiro and Monteiro, 2010). Their fruits are used as

food, lubricants, in the pharmaceutical industry, for the production of cosmetics and represent the main source of income of many agricultural-extractive communities (Leite et al., 2006; Moura et al., 2013). Fruits and leaves of

*e-mail: marcusasoares@yahoo.com.br

Received: April 10, 2020 - Accepted: June 29, 2020

This is an Open Access article distributed under the terms of the Creative Commons Attribution License, which permits unrestricted use, distribution, and reproduction in any medium, provided the original work is properly cited. 
C. brasiliense are also used in the folk medicine to treat many diseases (Vieira and Martins, 2000).

Caryocar brasiliense are protected under federal law in Brazil and these trees remain isolated in deforested areas, increasing vulnerability to attack by mites, such as Tetranychus sp. and Eutetranychus sp. (Tetranychidae) on leaves and Histiostoma sp. (Histiostomidae) on fruits (Leite et al., 2020). The need to monitor and understand pest damage to crops and forests is a major motivation for the study of population distributions. For this reasons the field of Arthropod population distributions has played a prominent role in the development of basic ecology and in the understanding and management of serious pests over the landscape (Price et al., 2011).

Predators play an essential role in the $C$. brasiliense trees habitat, occurring naturally and controlling phytophagous peaks in favorable periods. Important mite's predators have been observed in C. brasiliense trees, such as Agistemus sp. (Stigmaeidae) and Proctolaelaps sp. (Ascidae) (Leite et al., 2020). However, mites' population distributions on these trees are unknown.

The diversity and abundance of mites can vary among seasons, hot and dry seasons may increase their attacks (Silva et al., 2009; Lemtur and Choudhary, 2016). The hypotheses tested in this study are: 1) Phytophagous and predatory mites and their ecological indices are affected by the seasons, with peaks of occurrence depending on climatic conditions; 2) Phytophagous and predators could be influenced differently by seasons which could favor or hinder natural biological control. We investigated the effect of seasons in relation to the seasonal mite population distribution and their ecological indices on C. brasiliense trees.

\section{Material and Methods}

The study was conducted in the municipality of Montes Claros, Minas Gerais state, Brazil, from June 2016 to June 2019. The region has dry winters and rainy summers with an Aw climate: tropical savanna according to Köppen (Alvares et al., 2013). Three areas were evaluated: Cerrado stricto sensu, pasture (formerly Cerrado area), and urban area in the campus of the "Instituto de Ciências Agrárias da Universidade Federal de Minas Gerais (ICA/UFMG)". The more detailed description of these sites, theirs soils, the height and crown widths of $C$. brasiliense trees are available in Leite et al. (2006).

The design was completely randomized with 10 replicates (10 trees) per area and four treatments (seasons of the year) to check possible effects of weather conditions in the distribution of the mites populations. A border area of $100 \mathrm{~m}$ has been defined, and then, we walked ( $600 \mathrm{~m})$ in a straight line, in northeast direction, per area. One adult of $C$. brasiliense tree (producing fruits) was randomly sampled, every $50 \mathrm{~m}$, except at the urban area where the straight line walk was not used. Northeast direction is the predominant wind direction in this region's axis (Leite et al., 2006), favoring the transport of mites to the canopy trees (Tixier et al., 2000). Four expanded leaves, four flowers (Aug-Sep), and four fruits (Oct-Jan) from each stratum of the canopy (bottom, medium, and apical part) and from each cardinal orientation of branches of 30 trees (average height $3 \mathrm{~m}$ ) were monthly collected (in the morning) during those three years.

These plant materials were put in white plastic bags, which were sealed and transported to the laboratory where the number of immature and adults (sum) of mites (phytophagous and predators) were counted. The mites were counted within $2 \mathrm{~h}$ after collection, using a binocular microscope with $12.5 \times$ magnification for leaves and flowers, and direct counting on the fruits (no lens) (Castro et al., 2019). The mites were counted in three visual fields in the central part, the fields was equidistant between the principal vein and the margin, from each leaf (adaxial and abaxial surface) and randomly distributed in three fields on the flowers (Leite et al., 2020). Wholes fruits were evaluated. All counted mites were collected with brushes and preserved in vials with $70 \%$ alcohol for identification by Dr. A.L. Matioli and Dr. Eddie A. Ueckermann (only genus Agistemus).

The climatic data from June 2016 to June 2019, (temperature, rainfall, relative humidity of the air, sunshine, direction and wind speed) were obtained from the main climate station of Montes Claros of the "Estação Climatológica Principal do $5^{\circ}$ DISME-INMET" ( $16^{\circ} 84^{\prime} 10^{\prime \prime} \mathrm{S}$, $43^{\circ} 85^{\prime} 00^{\prime \prime} \mathrm{W}$ at an elevation of 646.29 masl).

Ecological indices (diversity and species richness) were calculated per identified mite species and treatment (seasons) using the BioDiversity Professional software, Version 2 (@1997, The Natural History Museum) (Krebs, 1989). Diversity was calculated using Hill's formula (Hill, 1973; Jost, 2006), and species richness was calculated using Simpson's indices (Begon et al., 2007; Lazo et al., 2007). Correlations of numbers of individuals of mites (phytophagous and predators) with climatic data and phytophagous vs. predators were subjected to Spearman's correlation $(P<0.05)$ using the statistical program System for Analysis Statistics and Genetics (SAEG), version 9.1 (SAEG, 2007) (Supplier: "Universidade Federal de Viçosa”). Number of mites (phytophagous and predators) data were transformed to $\sqrt{\mathrm{x}}+0.5$ and submitted to Lilliefor's normality test. The climatic, mite data and ecological indices were submitted to ANOVA $(P<0.05)$, and subsequently with Tukey's test $(P<0.05)$ using the SAEG.

\section{Results}

The herbivorous mites Acaridae, Eutetranychus sp., Tetranychus sp.1 and Tetranychus sp. 2 were observed on the leaves of $C$. brasiliense. The Histiostoma sp. on fruits. Predatory mites Agistemus sp. and Proctolaelaps sp. were observed, respectively, in leaves and fruits. Climate data (2016-2019) shows the highest temperature and rainfall in the spring, the relative humidity in the summer, sunlight in the autumn and winter and the lowest wind speed in the autumn.

Greatest number of Agistemus sp. $(\mathrm{F}=6.592, \mathrm{P}<0.001)$, Histiostoma sp. $(\mathrm{F}=7.051, \mathrm{P}<0.001)$, Proctolaelaps sp. $(\mathrm{F}=5.502, \mathrm{P}<0.001)$, and diversity $(\mathrm{F}=3.303, \mathrm{P}<0.04)$ and species richness $(\mathrm{F}=3.941, \mathrm{P}<0.02)$ on leaves of 
C. brasiliense occurred in the autumn; Tetranychus sp.1 $(\mathrm{F}=5.500, \mathrm{P}<0.001)$ on leaves in the autumn and winter; Histiostoma sp. $(\mathrm{F}=9.294, \mathrm{P}<0.001)$ and Proctolaelaps sp. $(\mathrm{F}=8.182, \mathrm{P}<0.001)$ in fruits in the summer. No significant effect of season was observed in the abundance of Eutetranychus sp., Tetranychus sp.2, and Acaridae. The largest individual mite peaks (three-year average $\pm S E$ ), per leaf, were observed in January (summer) to Agistemus sp. (10.11 \pm 10.11 ), March (end of summer) to Tetranychus sp.1
(9.67 $\pm 4,73)$, April (autumn) to Tetranychus sp.2 (4.24 $\pm 2.64)$, May (autumn) to Acaridae $(3.57 \pm 3.56)$ and Eutetranychus sp. $(1.33 \pm 1.33$ ), and June (end of autumn) to Histiostoma sp. (158.63 \pm 108.07$)$ and Proctolaelaps sp. (11.33 \pm 7.72 ) and, per fruit, February (summer) to Histiostoma sp. $(234.55 \pm 181.27)$ and Proctolaelaps sp. $(10.93 \pm 10.10)$ on C. brasiliense trees (Figure 1).

The highest temperature $(\mathrm{F}=25.709, \mathrm{P}<0.001)$ and rainfall $(\mathrm{F}=7.176, \mathrm{P}<0.001)$ were observed in spring,
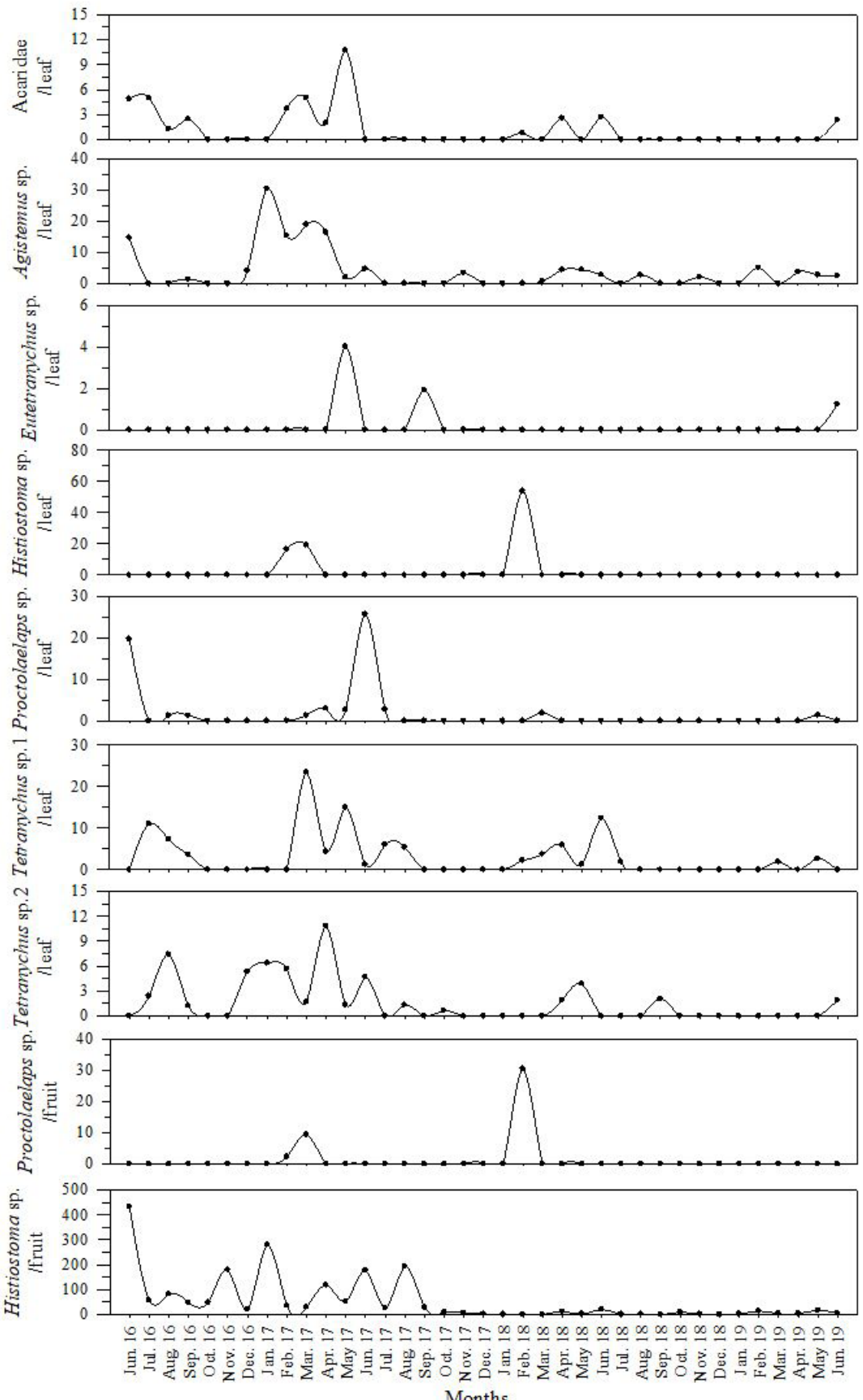

Figure 1. Number of Acaridae, Agistemus sp., Eutetranychus sp., Histiostoma sp., Proctolaelaps sp., and Tetranychus sp.1 and 2 on leaf (per $\mathrm{cm}^{2}$ ), and number of Proctolaelaps sp. and Histiostoma sp. per fruit on Caryocar brasiliense. Montes Claros, Minas Gerais State, Brazil. 
relative humidity of air $(\mathrm{F}=33.807, \mathrm{P}<0.001)$ in summer, and sunlight $(\mathrm{F}=11.085, \mathrm{P}<0.001)$ in autumn and winter, but the lowest velocity of wind $(\mathrm{F}=3.498, \mathrm{P}=0.01976)$ was noted in autumn (Table 1, Figure 2). Populations of Acaridae $(\mathrm{r}=-0.52, \mathrm{P}=0.0411)$, Eutetranychus sp., $(\mathrm{r}=-0.29$, $\mathrm{P}=0.0421)$, Proctolaelaps sp. $(\mathrm{r}=-0.61, \mathrm{P}=0.0213)$, and Tetranychus sp.1 $(\mathrm{r}=-0.54, \mathrm{P}=0.0376)$ were negatively correlated with temperature. Proctolaelaps sp. $(\mathrm{r}=-0.35$, $\mathrm{P}=0.0177)$ and Tetranychus sp. $1(\mathrm{r}=-0.38, \mathrm{P}=0.0111)$ correlated negatively with rainfall and Eutetranychus sp. $(r=0.43, P=0.0821)$ and Proctolaelaps sp. $(r=0.35$, $\mathrm{P}=0.0192)$ positively with sunlight. Agistemus sp. and Proctolaelaps sp. correlated positively with Acaridae $(\mathrm{r}=0.39, \mathrm{P}=0.0242$ and $\mathrm{r}=0.34, \mathrm{P}=0.0207$, respectively $)$ and Tetranychus sp.2 $(\mathrm{r}=0.55, \mathrm{P}=0.0002$ and $\mathrm{r}=0.51$, $\mathrm{P}=0.0011$, respectively). The two largest peaks of rainfall were observed in December 2016 (404.4 mm) and January 2019 ( $288.70 \mathrm{~mm}$ ) and virtually no mites were found on C. brasiliense trees during this period.

\section{Discussion}

The higher abundance of phytophagous mites and their predators per leaf and their ecological indices in autumn and winter and in fruits in summer confirm our first hypothesis that these mites and their ecological indices are affected by the seasons, with peaks of occurrence depending on climatic conditions. On the other hand, our second hypothesis with phytophagous and predators being influenced differently by the seasons has not been confirmed. This is, probably, because predators depend on their prey and follow them (Castro et al., 2014).

The higher abundance of phytophagous mites (e.g. Tetranychus sp.1) and their predators (e.g. Agistemus sp.), and their ecological indices (e.g. diversity) per leaf in the autumn and winter is, probably, due to the dry climate and low rainfall ( $1.04 \mathrm{~mm}$ per day) and air humidity ( $58.34 \%)$, moderate temperature $\left(22.47{ }^{\circ} \mathrm{C}\right)$, and high sunlight $(\sim 8.20 \mathrm{~h})$ on these seasons, that favors the development of these mites (Lemtur and Choudhary, 2016). On the other hand, the numbers of predators may also increase due to the increase in their prey density (Castro et al., 2014), being indirectly affected by the seasons. High population of phytophagous could be a threat to trees, because Tetranychus sp.1 and sp.2 and Eutetranychus sp., when in high populations, produce chlorotic spots on the leaves, reducing their photosynthetic capacity (Leite et al., 2020). In Citrus sinensis (L.) Osbeck (Rutaceae) orchard localized in São Paulo State, Brazil, the highest population size of predator mite Euseius concordis (Chant) (Phytoseiidae) was observed in hottest and rainiest period of the year,

Table 1. Number of mites ( $\mathrm{cm}^{2}$ of leaf) or per fruit, diversity and species richness ( $\mathrm{cm}^{2}$ of leaf $/$ tree), temperature $\left({ }^{\circ} \mathrm{C}\right)$, rainfall (mm), relative humidity of air (\%), sunlight (h), and velocity of wind (m/sec) (average \pm SE) according to the season of the year on Caryocar brasiliense. Montes Claros, Minas Gerais State, Brazil.

\begin{tabular}{|c|c|c|c|c|}
\hline \multirow{2}{*}{ Mites $/ \mathrm{cm}^{2}$ of leaf } & \multicolumn{4}{|c|}{ Season of the year } \\
\hline & Summer & Autumn & Winter & Spring \\
\hline Acari ${ }^{\text {n.s. }}$ & $0.0019 \pm 0.0007 \mathrm{~A}$ & $0.0066 \pm 0.0018 \mathrm{~A}$ & $0.0019 \pm 0.0009 \mathrm{~A}$ & $0.0000 \pm 0.0000 \mathrm{~A}$ \\
\hline Agistemus sp.* & $0.0086 \pm 0.0021 \mathrm{AB}$ & $0.0139 \pm 0.0032 \mathrm{~A}$ & $0.0019 \pm 0.0011 \mathrm{~B}$ & $0.0026 \pm 0.0014 \mathrm{~B}$ \\
\hline Eutetranychus sp. ${ }^{\text {n.s. }}$ & $0.0000 \pm 0.0000 \mathrm{~A}$ & $0.0013 \pm 0.0007 \mathrm{~A}$ & $0.0008 \pm 0.0008 \mathrm{~A}$ & $0.0000 \pm 0.0000 \mathrm{~A}$ \\
\hline Histiostoma sp.** & $0.0376 \pm 0.0094 \mathrm{C}$ & $0.0834 \pm 0.0094 \mathrm{~A}$ & $0.0675 \pm 0.0093 \mathrm{~B}$ & $0.0598 \pm 0.0157 \mathrm{~B}$ \\
\hline Proctolaelaps sp.** & $0.0010 \pm 0.0007 \mathrm{~B}$ & $0.0156 \pm 0.0061 \mathrm{~A}$ & $0.0022 \pm 0.0012 B$ & $0.0000 \pm 0.0000 \mathrm{~B}$ \\
\hline Tetranychus sp. $1^{* *}$ & $0.0059 \pm 0.0018 \mathrm{AB}$ & $0.0150 \pm 0.0034 \mathrm{~A}$ & $0.0124 \pm 0.0041 \mathrm{~A}$ & $0.0000 \pm 0.0000 \mathrm{~B}$ \\
\hline Tetranychus sp. $2^{\text {n.s. }}$ & $0.0017 \pm 0.0010 \mathrm{~A}$ & $0.0060 \pm 0.0018 \mathrm{~A}$ & $0.0038 \pm 0.0016 \mathrm{~A}$ & $0.0011 \pm 0.0008 \mathrm{~A}$ \\
\hline \multicolumn{5}{|l|}{ Mites/fruit } \\
\hline Histiostoma sp.* & $76.76 \pm 18.67 \mathrm{~A}$ & $0.00 \pm 0.00 \mathrm{~B}$ & $0.00 \pm 0.00 \mathrm{~B}$ & $0.00 \pm 0.00 \mathrm{~B}$ \\
\hline Proctolaelaps sp.* & $2.80 \pm 0.79 \mathrm{~A}$ & $0.00 \pm 0.00 \mathrm{~B}$ & $0.00 \pm 0.00 \mathrm{~B}$ & $0.00 \pm 0.00 \mathrm{~B}$ \\
\hline \multicolumn{5}{|l|}{ Ecological indices } \\
\hline Diversity** & $3.82 \pm 1.02 \mathrm{AB}$ & $5.19 \pm 1.36 \mathrm{~A}$ & $3.54 \pm 0.87 \mathrm{AB}$ & $1.96 \pm 0.32 \mathrm{~B}$ \\
\hline Species richness* & $2.70 \pm 0.65 \mathrm{AB}$ & $3.60 \pm 0.71 \mathrm{~A}$ & $2.70 \pm 0.73 \mathrm{AB}$ & $1.60 \pm 0.26 \mathrm{~B}$ \\
\hline \multicolumn{5}{|l|}{ Variables } \\
\hline Temperature** & $24.10 \pm 0.11 \mathrm{~B}$ & $22.16 \pm 0.30 \mathrm{C}$ & $22.78 \pm 0.23 \mathrm{C}$ & $25.05 \pm 0.27 \mathrm{~A}$ \\
\hline Rainfall** & $5.15 \pm 0.73 \mathrm{~B}$ & $1.04 \pm 0.35 \mathrm{~B}$ & $1.03 \pm 0.40 \mathrm{~B}$ & $22.48 \pm 7.59 \mathrm{~A}$ \\
\hline Humidity* & $75.80 \pm 1.21 \mathrm{~A}$ & $64.31 \pm 1.51 \mathrm{~B}$ & $52.36 \pm 0.98 \mathrm{C}$ & $63.97 \pm 2.80 \mathrm{~B}$ \\
\hline Sunlight** & $5.98 \pm 0.32 B$ & $8.33 \pm 0.16 \mathrm{~A}$ & $8.06 \pm 0.20 \mathrm{~A}$ & $6.84 \pm 0.56 \mathrm{~B}$ \\
\hline Wind $^{* *}$ & $2.48 \pm 0.29 \mathrm{~A}$ & $1.80 \pm 0.02 \mathrm{~B}$ & $2.30 \pm 0.06 \mathrm{~A}$ & $2.12 \pm 0.03 \mathrm{AB}$ \\
\hline
\end{tabular}

Means followed by the same letter (average $\pm \mathrm{SE}$ ) in each row are not different by the test of Tukey $\left({ }^{*}=\mathrm{P}<0.01\right.$ and $\left.{ }^{* *}=\mathrm{P}<0.05\right)$. Freedom degree: mites/leaf $=5281$, mites/fruit $=2184$, ecological indices $=27$, and climatic data $=72$, "n.s." = non-significant data. 

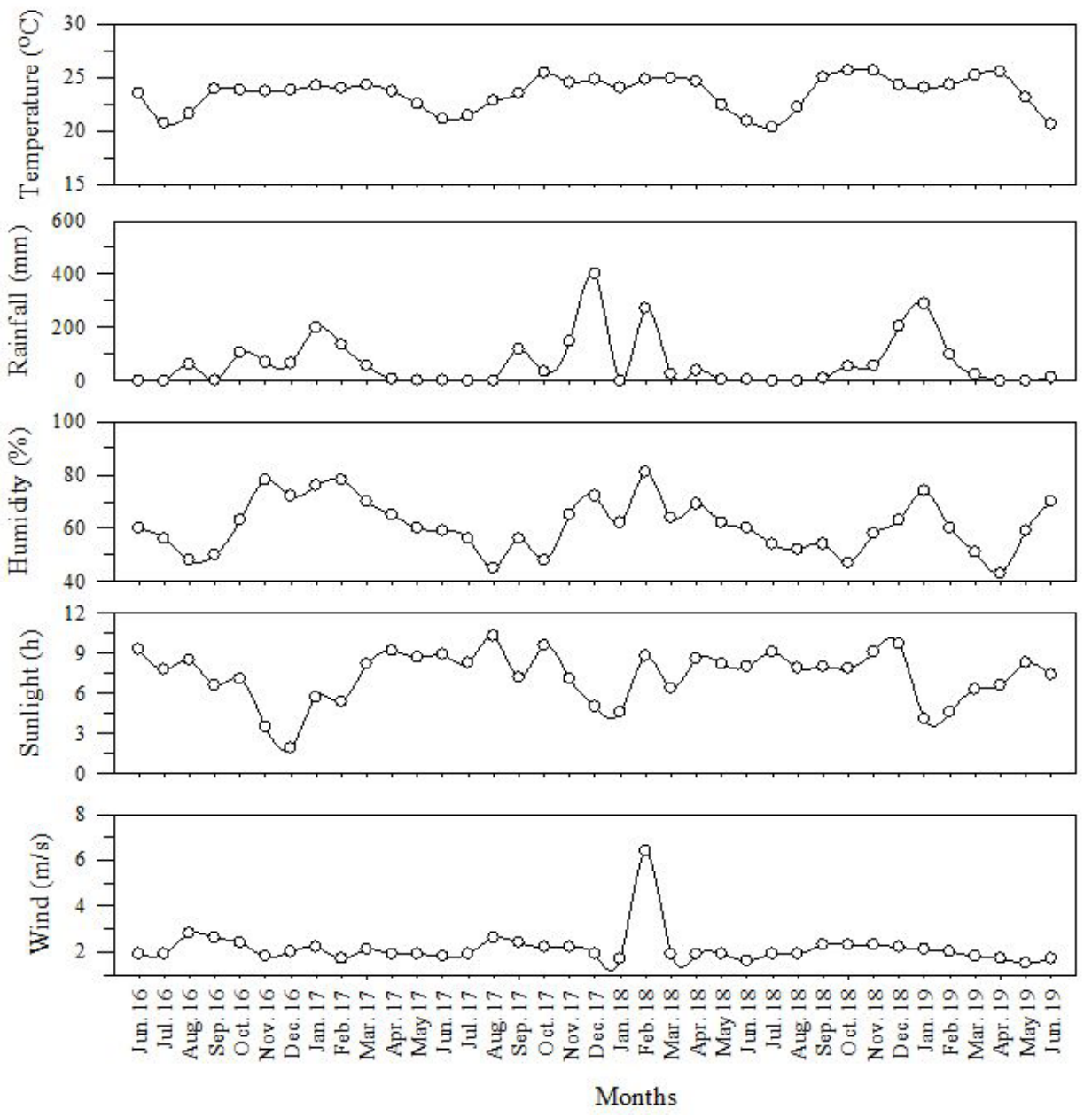

Figure 2. Temperature $\left({ }^{\circ} \mathrm{C}\right)$, rainfall $(\mathrm{mm})$, relative humidity of air $(\%)$, sunlight $(\mathrm{h})$, and velocity of wind $(\mathrm{m} / \mathrm{sec})$. Montes Claros, Minas Gerais State, Brazil.

but for Phyllocoptruta oleivora (Ashmed) (Eriophyidae) and Brevipalpus phoenicis (Geijskes) (Tenuipalpidae), both important pests for this plant, this period had smallest populations (Silva et al., 2012). Tetranychus kanzawai Kishida (Tetranychidae) feeding on Malus domestica (Borkh.) (Rosaceae) leaves increased its intrinsic rate of growth with the temperature raising from $0.043 \mathrm{day}\left({ }^{-1}\right)$ at $15^{\circ} \mathrm{C}$ to $0.252 \operatorname{day}\left({ }^{-1}\right)$ at $30{ }^{\circ} \mathrm{C}$, then decreased to $0.134 \operatorname{day}\left({ }^{-1}\right)$ at $37.5^{\circ} \mathrm{C}$ (Hasanvand et al., 2019). Tetranychus evansi Baker and Pritchard (Tetranychidae), a pest of solanaceous crops, showed high adaptability to a wide range of summer temperatures, explaining their current distribution.

Climate changes may favor mites spread and expand its distribution (Ghazy et al., 2019) because many species increase their population and injuries to plants in warmer climates. On the other hand, Tetranychus ludeni Zacher (Tetranychidae) has best performance at $22-28{ }^{\circ} \mathrm{C}$ and the worst at $29-35^{\circ} \mathrm{C}$, suggesting that this mite could to invade regions with temperate weather (Ristyadi et al., 2019). This shows the importance of knowing the population distributions of pests and developing mechanisms to correlate their occurrence with the climate.
Another explanation for the greater abundance of phytophagous and predators mites on $C$. brasiliense leaves in the autumn and winter is probably determined by the reduction in the number of $C$. brasiliense leaves available due to their gradual loss during the dry period and by the end of last season (winter) (Leite et al., 2006), which can result in a concentration of mites per leaf in this plant, such as observed for other insect groups (e.g. coleopteran) in this same plant (Leite et al., 2012, 2013). The highest number of Histiostoma sp. (phytophagous mite) and Proctolaelaps sp. (predator mite) on fruits during the summer is due to the end of fruit production (Leite et al., 2006), also concentrating these mites.

The largest numbers of predator mite Agistemus sp. on leaves on autumn, and Proctolaelaps sp. on fruits on summer, probably, indicate that their populations responded to an increase in their prey density (Matioli et al., 1998; Castro et al., 2014). The correlation between Agistemus sp. and Tetranychus sp.1 on C. brasiliense leaves was positive in Cerrado, pasture and urban areas (Leite et al., 2020). This shows that this predator is the main biological controller of this phytophagous mite. 


\section{Conclusions}

The period with low rainfall and relative humidity increases mites (phytophagous and predators) and their ecological indices. The Tetranychus sp. and Histiostoma sp. species may become pests in C. brasiliense in the Cerrado domain. Agistemus sp. could be used as an important predator of these mites.

\section{References}

ALVARES, C.A., STAPE, J.L., SENTELHAS, P.C., GONÇALVES, J.L.M. and SPAROVEK, G., 2013. Köppen's climate classification map for Brazil. Meteorologische Zeitschrift, vol. 22, no. 6, pp. 711-728. http://dx.doi.org/10.1127/0941-2948/2013/0507.

BEGON, M., TOWNSEND, C.R. and HARPER, J.L., 2007 [viewed 30 June 2018]. Ecologia: de indivíduos a ecossistemas [online]. 4. ed. Porto Alegre: Artmed, 752 p. Available from: http:/www. esalq.usp.br/lepse/imgs/conteudo_thumb/ Ecology-FromIndividuals-to-ecosystems-by-Michael-Begon-2007-.pdf

CASTRO, B.M.C., SOARES, M.A., ANDRADE JUNIOR, V.C., FADINI, M.A.M., FERREIRA, J.A.M. and MORAES, G.J., 2014. The predatory mite Phytoseiulus macropilis (Acari: Phytoseiidae) occurring on sweet potato (Ipomoea batatas) plants in Diamantina, Minas Gerais State, Brazil. Brazilian Journal of Biology $=$ Revista Brasileira de Biologia, vol. 74, no. 3, pp. 685-686. http://dx.doi. org/10.1590/bjb.2014.0078. PMid:25296218.

CASTRO, B.M.C., SOARES, M.A., ANDRADE JÚNIOR, V.C., SANTOS JÚNIOR, V.C., FONTES, P.C.R., WILCKEN, C.F., SERRÃO, J.E. and ZANUNCIO, J.C., 2019. Preference of red mite Tetranychus ludeni Zacher (Acari: Tetranychidae) to sweet potato genotypes. Brazilian Journal of Biology = Revista Brasileira de Biologia, vol. 79, no. 2, pp. 208-212. http://dx.doi.org/10.1590/1519-6984.176665. PMid:29947646.

GHAZY, N.A., GOTOH, T. and SUZUKI, T., 2019. Impact of global warming scenarios on life-history traits of Tetranychus evansi (Acari: tetranychidae). BMC Ecology, vol. 19, no. 1, pp. 48. http://dx.doi.org/10.1186/s12898-019-0264-6. PMid:31771563.

HASANVAND, I., JAFARI, S. and KHANJANI, M., 2019. Effect of temperature on development and reproduction of Tetranychus kanzawai (Tetranychidae), fed on apple leaves. International Journal of Acarology, vol. 46, no. 1, pp. 31-40. http://dx.doi.org /10.1080/01647954.2019.1694582.

HILL, M.O., 1973. Diversity and evenness: a unifying notation and its consequences. Ecology, vol. 54, no. 2, pp. 427-432. http:// dx.doi.org/10.2307/1934352.

JOST, L., 2006. Entropy and diversity. Oikos, vol. 113, no. 2, pp. 363-375. http://dx.doi.org/10.1111/j.2006.0030-1299.14714.x.

KREBS, C.J., 1989 [viewed 2 May 2016]. BioDiversity Pro Versão 2 [software]. Available from: http://biodiversity-pro.software. informer.com/

LAZO, J.A., VALDES, N.V., SAMPAIO, R.A. and LEITE, G.L.D., 2007. Diversidad zoológica asociada a un silvopastoreo leucaenaguinea con diferentes edades de establecimiento. Pesquisa Agropecuária Brasileira, vol. 42, no. 12, pp. 1667-1674. http:// dx.doi.org/10.1590/S0100-204X2007001200001.

LEITE, G.L.D., VELOSO, R.V.D.S., ZANUNCIO, J.C., FERNANDES, G.W., ALMEIDA, C.I.M., FERREIRA, P.S.F., ALONSO, J. and SERRÃO, J.E., 2012. Seasonal abundance of hemipterans on Caryocar brasiliense (Malpighiales: Caryocaraceae) trees in the Cerrado. The Florida Entomologist, vol. 95, no. 4, pp. 862-872. http:// dx.doi.org/10.1653/024.095.0407.
LEITE, G.L.D., VELOSO, R.V.S., MATIOLI, A.L., ALMEIDA, C.I.M., SOARES, M.A., ALVES, P.G.L. and ZANUNCIO, J.C., 2020. Habitat complexity and mite population on Caryocar brasiliense trees. Acta Scientiarum. Agronomy. In press.

LEITE, G.L.D., VELOSO, R.V.S., ZANUNCIO, J.C., FERNANDES, G.W., ALMEIDA, C.I.M., PEREIRA, J.M.M., SERRÃO, J.E. and SOARES, M.A., 2013. Seasonal abundance of galling insects (Hymenoptera) on Caryocar brasiliense (Malpighiales: Caryocaraceae) trees in the Cerrado. The Florida Entomologist, vol. 96, no. 3, pp. 797-809. http://dx.doi.org/10.1653/024.096.0313.

LEITE, G.L.D., VELOSO, R.V.S., ZANUNCIO, J.C., FERNANDES, L.A. and ALMEIDA, C.I.M., 2006. Phenology of Caryocar brasiliense in the Brazilian Cerrado Region. Forest Ecology and Management, vol. 236, no. 2-3, pp. 286-294. http://dx.doi.org/10.1016/j. foreco.2006.09.013.

LEMTUR, M. and CHOUDHARY, J.S., 2016. Influence of weather parameters on population dynamics of thrips and mites on summer season cowpea in Eastern Plateau and Hill region of India. Journal of Agrometeorology, vol. 18, no. 2, pp. 296-299.

MATIOLI, A.L., LEITE, G.L.D., PALLINI FILHO, A. and PICANÇO, M.C., 1998. Distribuição espacial e temporal e efeito de diferentes tratos culturais em ácaros associados a laranja pêra-rio. Agrociencia, vol. 14, no. 1, pp. 395-405.

MOURA, M.F., CHAVES, L.J. and NAVES, R.V., 2013. Characterization of pequi fruits (Caryocar brasiliense Camb.) from Brazilian cerrado. Revista Árvore, vol. 37, no. 5, pp. 905-912. http://dx.doi. org/10.1590/S0100-67622013000500013.

PINHEIRO, M.H.O. and MONTEIRO, R., 2010. Contribution to the discussions on the origin of the cerrado biome: brazilian savanna. Brazilian Journal of Biology = Revista Brasileira de Biologia, vol. 70, no. 1, pp. 95-102. http://dx.doi.org/10.1590/ S1519-69842010000100013. PMid:20231964.

PRICE, P., DENNO, R., EUBANKS, M., FINKE, D. and KAPLAN, I. 2011. Insect ecology: behavior, populations and communities. Cambridge: Cambridge University Press, Population dynamics, pp. 404-440. http://dx.doi.org/10.1017/CBO9780511975387.016.

RISTYADI, D., HE, X.Z. and WANG, Q., 2019. Dynamics of life history traits in Tetranychus ludeni Zacher in response to fluctuating temperatures. Systematic and Applied Acarology, vol. 24, no. 11, pp. 2272-2277. http://dx.doi.org/10.11158/saa.24.11.16.

SILVA, F.W.S., LEITE, G.L.D., GUANABENS, R.E.M., MARTINS, E.R., MATIOLI, A.L. and FERNANDES, L.A., 2009. Nutrientes afetando as mudas de alecrim-pimenta (Lippia sidoides Cham.) e seus artrópodes. Revista Brasileira de Plantas Medicinais, vol. 11, no. 1, pp. 18-23. http://dx.doi.org/10.1590/S151605722009000100004.

SILVA, M.Z., SATO, M.E. and OLIVEIRA, C.A.L., 2012. Diversity and population dynamics of mites in citrus orchard. Bragantia, vol. 71, no. 2, pp. 210-218. http://dx.doi.org/10.1590/S000687052012005000013.

SISTEMA PARA ANÁLISES ESTATÍSTICAS - SAEG, 2007 [viewed 30 June 2018]. Sistema para Análises Estatísticas - SAEG Versão 9.1 [online]. Available from: http://arquivo.ufv.br/saeg/

TIXIER, M.S., KREITER, S. and AUGER, P., 2000. Colonization of vineyards by phytoseiid mites: their dispersal patterns in the plot and their fate. Experimental \& Applied Acarology, vol. 24, no. 3, pp. 191-211. http://dx.doi.org/10.1023/A:1006332422638. PMid:11108386.

VIEIRA, R.F. and MARTINS, M.V.M., 2000. Recursos genéticos de plantas medicinais de cerrado: uma compilação de dados. Brazilian Journal of Medicinal Plants, vol. 3, pp. 13-36. 